\title{
Study and Analysis of Scientific Scopes and Issues towards Developing an Efficient LECIM
}

\author{
Shah Murtaza Rashid Al \\ Masud \\ Faculty of Computer Science \\ and Information Systems \\ Najran University \\ Najran, Saudi Arabia
}

\begin{abstract}
In the field of communication technology the wireless networking system is rapidly escalating. Due to the usefulness and huge applications of this modern technology it is very important to make the system more effective to the users. In the functional point of view the effectiveness requiring certain criteria including lower energy consumption, security, reliability and lower cost. The recent development of low energy critical infrastructure monitoring (LECIM) [under IEEE P802.15 WPAN's task group TG4k] has vast applications including various monitoring and tracking systems. To accomplish the major quality issues and come up into a common and reachable goal LECIM requires more research and enormous concentration. At this moment a vast research scope is open for researchers. In this research paper the authors studied and analyzed the issues, scopes, usefulness, characteristics, requirements, topology, several comparative studies, existing MAC protocols for LECIM and wireless networks, and exiting LECIM applications for further development and improvement of LECIM networks, infrastructures, and applications. This paper will be very helpful for academicians, researchers, and industries towards constructing an efficient and effective LECIM.
\end{abstract}

\section{General Terms}

Wireless Networks, LECIM

\section{Keywords}

LECIM, WPAN, IEEE, MAC, Network, Applications

\section{INTRODUCTION}

In current research epoch critical infrastructure monitoring is one of the foremost and interested domains for researchers, and academicians. Towards effective and better functioning of a society as well as the economy of a society it's important to define and describe some assets and infrastructures those are essential and it can be expressed by using the term critical infrastructure [1]. This is very important to ensure monitoring in order to ensure the preventive maintenance, safety, and reliability. It helps to reduce the overall cost, but at the same time it improves operations, efficiency and increases reliability, reduces outage, speeds up the restoration service and increases safety through the prevention of catastrophic failures, environmental damage, and hazardous leaks [2]. The aforesaid features necessitate enormously low energy usage to maximize the deployment lifetime which are considered as LECIM network. Long lifetime for battery, low energy or energy efficiency, scalability, consistency or reliability, accessibility or availability, robustness or strength, maintainability, and safety or security is the main provisions for such a network [3]. The challenging environment including cities, rural areas, forests, mountains, and below/ underground locations are the required low energy based territory where power mains and the network infrastructures are not readily available. All the endpoints in this network are extremely disseminated and the distance between coordinator and these endpoints may vary up to 20 kilometers and also need to operate for long durations without human interactions. Towards concentrating on LECIM that should support simple and low cost communication environment with consistent or reliable data transfer capabilities, long life battery and power management of the radio the IEEE Task Group $4 \mathrm{k}$ is created which is the member of the family IEEE 802.15. LECIM is one of the very recent and new eras in modern information and communication technologies having unique features that require a huge research. In this research paper the authors are studied and analyzed most of the important issues necessitate for further advancement of its architecture, network infrastructure, management along with low energy, high battery life and low cost operations.

The rest of the paper is structured as follows. In Section 2 usefulness of monitoring applications are explicated. In Section 3 areas of LECIM applications are mentioned. In Section 4, we discussed existing wireless network architecture and LECIM Network. In Section 5, LECIM network and applications requirements are defined. In Section 6, LECIM network model and topology are presented. In Section 7, Operating frequency bands for LECIM are defined. In Section 8 , we explained existing MAC protocol for LECIM network. In Section 9, we discussed existing LECIM applications. Finally, we conclude and discuss future work in Section 10.

\section{USEFULNESS OF MONITORING APPLICATIONS}

It is very important to ensure proper management and monitoring systems for various critical infrastructure applications which ultimately enhances operational efficiency. The basic needs for monitoring and management [2] are illustrated in Table 1. 
Table 1: Usefulness of LECIM

\begin{tabular}{|c|l|}
\hline Main Issues & \multicolumn{1}{|c|}{ Explanation } \\
\hline $\begin{array}{c}\text { Preventive } \\
\text { maintenance }\end{array}$ & $\begin{array}{l}\text { Repairs can be scheduled, costs are } \\
\text { reduced }\end{array}$ \\
\hline Safety & $\begin{array}{l}\text { Prevention of catastrophic failures, } \\
\text { environmental damage, hazardous } \\
\text { leaks/spills }\end{array}$ \\
\hline Reliability & $\begin{array}{l}\text { Reduces outage and speeds restoration } \\
\text { of service }\end{array}$ \\
\hline Cost reduction & $\begin{array}{l}\text { Cost reduction can be achieved } \\
\text { through improved operations and } \\
\text { efficiency }\end{array}$ \\
\hline
\end{tabular}

\section{AREAS OF LECIM APPLICATIONS}

Outdoor environment is primarily selected for LECIM applications as presented in Figure 1. The main areas of applications [4] are depicted in Table 2. All these applications are further specifically categorized into four main groups [5] as presented in Table 3. These four categories of LECIM applications are: infrastructure monitoring, transportation and asset tracking, security and life safety, and periodic traffic monitoring.

Table 2: LECIM: Main areas of applications

\begin{tabular}{|c|c|}
\hline Main Areas & LECIM Applications \\
\hline Area 1 & $\begin{array}{l}\text { Electricity generation, transmission and } \\
\text { distribution }\end{array}$ \\
\hline Area 2 & Gas production, transport and distribution \\
\hline Area 3 & $\begin{array}{l}\text { Oil and oil products production, transport } \\
\text { and distribution }\end{array}$ \\
\hline Area 4 & Telecommunication \\
\hline Area 5 & $\begin{array}{l}\text { 3.1.1 Water supply (drinking water, } \\
\text { waste water/sewage, stemming of surface } \\
\text { water (e.g. dikes and sluices)) }\end{array}$ \\
\hline Area 6 & $\begin{array}{l}\text { Agriculture, food production and } \\
\text { distribution }\end{array}$ \\
\hline Area 7 & $\begin{array}{l}\text { 3.1.2 Heating (e.g. natural gas, fuel oil, } \\
\text { district heating) }\end{array}$ \\
\hline Area 8 & $\begin{array}{l}\text { 3.1.3 Public health (hospitals, } \\
\text { ambulances) } \\
\text { 3.1.4 }\end{array}$ \\
\hline Area 9 & $\begin{array}{l}\text { 3.1.5 Transportation systems (fuel } \\
\text { supply, railway network, airports, } \\
\text { harbours, inland shipping) }\end{array}$ \\
\hline Area 10 & $\begin{array}{l}\text { 3.1.6 Financial services (banking, } \\
\text { clearing) }\end{array}$ \\
\hline
\end{tabular}

\begin{tabular}{|c|lr|}
\hline Area 11 & 3.1 .7 & Security services (police, military) \\
\hline Area 12 & $\begin{array}{l}3.1 .8 \\
\text { (emissions, chemicals) }\end{array}$ & monitoring \\
\hline
\end{tabular}

\section{EXISTING WIRELESS NETWORK ARCHITECTURE AND LECIM NETWORK}

Existing architecture based on wireless communication network can't support the LECIM applications because LECIM architecture requires low energy, long life battery, low data rate and low cost communication infrastructure. The Table 4 shows the differences between existing architecture of several wireless technologies and LECIM requirements towards critical infrastructure monitoring. IEEE 802 standard for wireless technology consists of some working groups which support various wireless applications namely IEEE 802.11 WLAN, IEEE 802.15 WPAN or more specifically 15.1 Bluetooth, 15.3 Multimedia, 15.4e, 15.4f RFID, 15.4k LECIM, 15.6 BAN, 15.7 Visible light communication, IEEE 802.16 WMAN, IEEE 802.20 MBWA, IEEE 802.22 WRAN. The Table 5 shows the main characteristics of these existing technologies and their limitations towards fulfill the essential LECIM that is $15.4 \mathrm{k}$ requirements. The operating space of various WLAN and WPAN shows the increasing and decreasing rate of these networks' complexity, power consumption rate, and data flow rate as depicted in Figure 2 [6].

\section{LECIM NETWORK AND APPLICATIONS REQUIREMENTS}

Requirements of LECIM are based on LECIM network that is infrastructures and LECIM applications. Low energy, long lifetime, scalability, reliability, availability, robustness, maintainability, and security are network based requirements, where large path loss, minimal infrastructure requirements, and multi-year battery life are applications based requirements. The overall LECIM requirements are illustrated in Table 6 [7] [8] [9]. And design requirements on LECIM MAC are illustrated in Table 7 [10].

Table 4: Existing architecture vs. LECIM

\begin{tabular}{|c|l|}
\hline $\begin{array}{c}\text { Existing } \\
\text { Architecture }\end{array}$ & \multicolumn{1}{|c|}{ Main Features } \\
\hline Satellite link & $\begin{array}{l}\text { High power, High cost, Subscriber } \\
\text { fees }\end{array}$ \\
\hline Cellular & $\begin{array}{l}\text { High power, Coverage, Subscriber } \\
\text { fees }\end{array}$ \\
\hline Wireless SCADA & $\begin{array}{l}\text { High unit, and installation costs, } \\
\text { Limited capacity, High power, } \\
\text { Proprietary }\end{array}$ \\
\hline LECIM & $\begin{array}{l}\text { Low power, Low cost, Long life } \\
\text { battery, Low data rate, Long distance } \\
\text { territory. }\end{array}$ \\
\hline
\end{tabular}




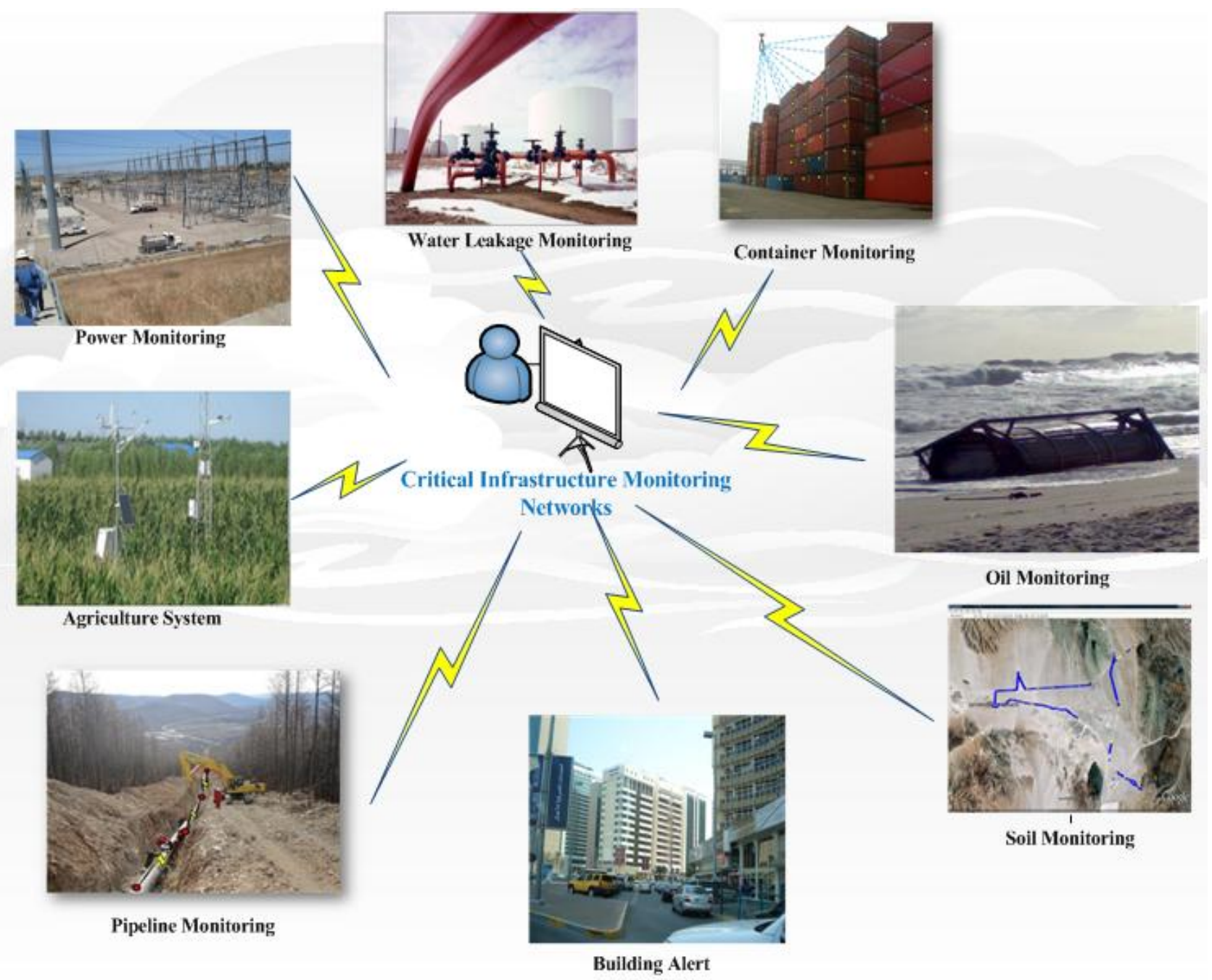

Figure 1: LECIM applications monitoring networks

Table 3: Specifically categorized of LECIM applications

\begin{tabular}{|c|c|c|c|}
\hline Infrastructure Monitoring & $\begin{array}{c}\text { Transportation and Asset } \\
\text { tracking }\end{array}$ & Security and Life Safety & $\begin{array}{l}\text { Periodic traffic } \\
\text { monitoring }\end{array}$ \\
\hline $\begin{array}{l}\text { - Urban WSN } \\
\text { - Water leak detection } \\
\text { - Sewer monitoring } \\
\text { - Structural integrity monitoring } \\
\text { - Building monitoring } \\
\text { - Streetlight control systems } \\
\text { - Soil monitoring } \\
\text { - Oil and gas pipeline } \\
\text { - } \text { Agnitoring } \\
\text { - Electric substation monitoring } \\
\text { - Location tracking } \\
\text { - Wastewater monitoring } \\
\text { - Machine/Server } \\
\text { - } \text { monitoring rirst Responder monitoring } \\
\text { - border surveillance } \\
\text { - Car parking management }\end{array}$ & 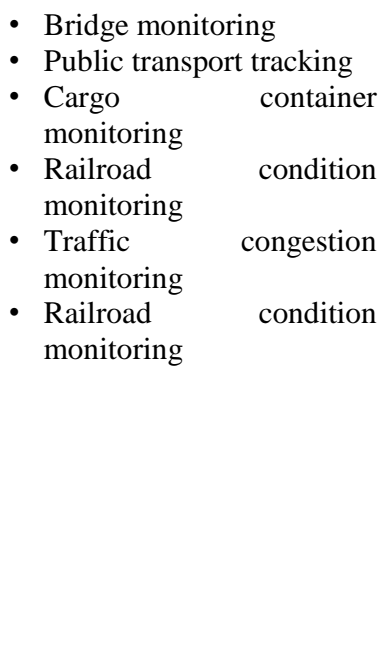 & $\begin{array}{l}\text { - } \text { Personal tracking } \\
\text { - Gas/hazardous material } \\
\text { detection } \\
\text { - Perimeter security } \\
\text { - Fault Circuit Indicators } \\
\text { - } \text { Border surveillance } \\
\text { - } \text { Medical alert for at-risk } \\
\text { - First responder tracking }\end{array}$ & $\begin{array}{l}\text { - Gas meter } \\
\text { - Water meter } \\
\text { - Electric meter } \\
\text { - Net metering } \\
\text { - Transformer load } \\
\text { monitoring }\end{array}$ \\
\hline
\end{tabular}


Table 5: Main characteristics of IEEE 802 Standards and 15.4k LECIM

\begin{tabular}{|c|c|c|c|}
\hline \multicolumn{3}{|c|}{ IEEE 802 Standards } & Characteristics \\
\hline \multicolumn{3}{|l|}{$\begin{array}{l}802.11 \text { WLAN } \\
\text { Wi-Fi Networks }\end{array}$} & $\begin{array}{l}\text { Applicable for computing and smart phone. High data rate, } \\
\text { high duty cycle, and high performance in areas such as } \\
\text { QOS and roaming. High power, not suitable for multi-year } \\
\text { battery life. Local area coverage. }\end{array}$ \\
\hline \multicolumn{3}{|r|}{ 15.1 Bluetooth } & $\begin{array}{l}\text { Short range. Low capacity, cannot support thousands of } \\
\text { endpoints due to low capacity. Focused on apps of } \\
\text { multimedia and regular recharging }\end{array}$ \\
\hline \multirow{6}{*}{ 802.15 WPAN } & \multicolumn{2}{|r|}{ 15.3 Multimedia } & High rate (multimedia). High data rate applications \\
\hline & \multirow{3}{*}{15.4} & $15.4 \mathrm{e}$ & $\begin{array}{l}\text { It supports low data rate applications. It supports mainly } \\
\text { TDMA approach which cannot work well for LECIM } \\
\text { networks due to large number of endpoints. }\end{array}$ \\
\hline & & 15.4f RFID & $\begin{array}{l}\text { Main focus is for very low cost with no mechanisms to } \\
\text { enhance range. }\end{array}$ \\
\hline & & 15.4k LECIM & $\begin{array}{l}\text { Main focus is low rate, low energy critical infrastructure } \\
\text { monitoring. It must support low cost, long life battery, long } \\
\text { distance territory (between coordinator and large number of } \\
\text { endpoints) }\end{array}$ \\
\hline & & 15.6 BAN & $\begin{array}{l}\text { Short range. Wireless communication in the vicinity of, or } \\
\text { inside, a human body }\end{array}$ \\
\hline & 15.7 & ble Light Communications & $\begin{array}{l}\text { Short range optical wireless communication using visible } \\
\text { light }\end{array}$ \\
\hline & 802.16 & MAN & $\begin{array}{l}\text { Supports broadband- high data rate wireless access for } \\
\text { metropolitan area network }\end{array}$ \\
\hline & 802.20 & WA & Mobile broadband that high data rate wireless access \\
\hline & 802.22 & RAN & $\begin{array}{l}\text { Wireless Regional Area Network designed for broadband } \\
\text { that is high data rate. High architectural complexity. High } \\
\text { cost. Infrastructure intensive. High power. Cell phone } \\
\text { battery life, supports } .16 \mathrm{~m} \text {. Medium capacity (users). }\end{array}$ \\
\hline
\end{tabular}

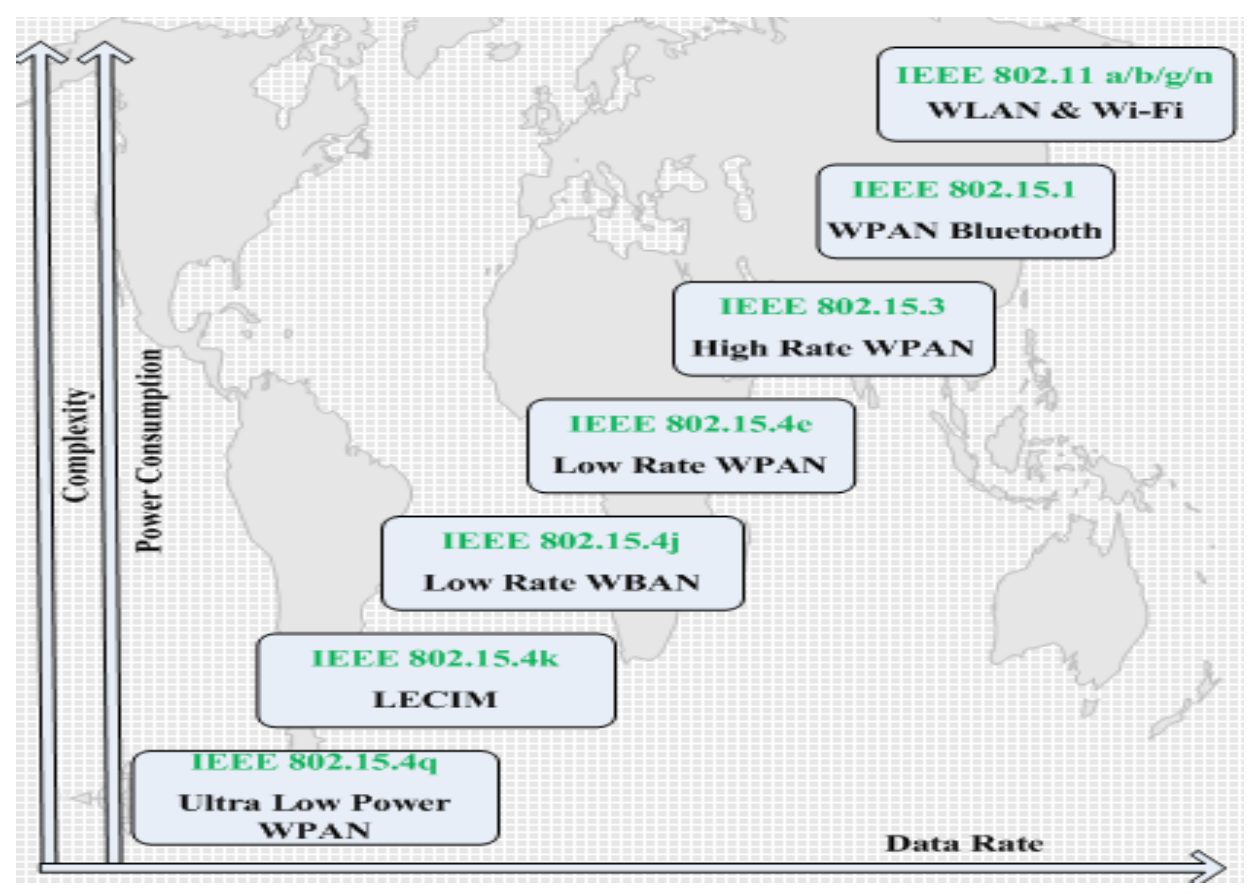

Figure 2: The operating space of various WLAN and WPAN 
Table 6: LECIM requirements

\begin{tabular}{|c|c|}
\hline $\begin{array}{c}\text { Serial } \\
\text { Number }\end{array}$ & Description \\
\hline LR1* & $\begin{array}{l}\text { Simultaneous operation for at least } 8 \text { co-located } \\
\text { orthogonal networks }\end{array}$ \\
\hline LR2 & Application data rate vary from 1 to $40 \mathrm{kbps}$ \\
\hline LR3 & Propagation path loss of at least $120 \mathrm{~dB}$ \\
\hline LR4 & $\begin{array}{l}\text { Communication between main-powered } \\
\text { coordinator and large number of endpoints, } \\
>1000 \text { endpoints per mains powered } \\
\text { infrastructure }\end{array}$ \\
\hline LR5 & Asymmetric application data flow \\
\hline LR6 & Ultra-low maintenance traffic \\
\hline LR7 & $\begin{array}{l}\text { Low power consumption, end point need to } \\
\text { periodically go to sleep to conserve energy }\end{array}$ \\
\hline LR8 & High channel access efficiency is required \\
\hline LR9 & $\begin{array}{l}\text { Primarily outdoor environment with minimal } \\
\text { network infrastructure }\end{array}$ \\
\hline LR10 & $\begin{array}{l}\text { Long deployment life with/ without human } \\
\text { contact (long lived infra more than } 10 \text { years life } \\
\text { like network carrier's infra, ease maintained } \\
\text { monitoring network, high degree of freedom to } \\
\text { start the monitoring/maintenance business) }\end{array}$ \\
\hline LR11 & $\begin{array}{l}\text { Need low energy operation necessary for multi- } \\
\text { year battery life (>20 year) }\end{array}$ \\
\hline LR12 & Tolerant to data latency \\
\hline LR13 & Small, infrequent messages \\
\hline LR14 & $\begin{array}{l}\text { Network devices: Coordinator (Collector) } \\
\text { typically mains powered (rarely available). End } \\
\text { point devices are typically battery powered } \\
\text { (Battery operation (up to } 20 \text { years), low energy } \\
\text { consumption, Low duty cycle). No mobility of } \\
\text { end devices but portability for coordinator. }\end{array}$ \\
\hline LR15 & Low node density( long range) \\
\hline LR16 & Mobility (Asset tracking, Dynamic fail-over) \\
\hline LR17 & $\begin{array}{l}\text { Worldwide use(Operates in all regulatory } \\
\text { domains, Low transmit power compliant with } \\
\text { international regulations) }\end{array}$ \\
\hline LR18 & $\begin{array}{l}\text { Low cost(Low operational cost: unlicensed, } \\
\text { lightly licensed spectrum, Low infrastructure, } \\
\text { maintenance, and system cost, Ease of } \\
\text { deployment) }\end{array}$ \\
\hline LR19 & Must be compatible with existing MAC \\
\hline LR20 & $\begin{array}{l}\text { PHY packet size for LECIM: Typical packet } \\
\text { duration "real world" ranges from }<1 \mathrm{~ms} \text { to } \\
\sim 16 \mathrm{~ms}\end{array}$ \\
\hline LR21 & Aim to collect the scheduled and event data \\
\hline LR22 & $\begin{array}{l}\text { Aim to minimize the network maintenance } \\
\text { traffic and endpoint active durations }\end{array}$ \\
\hline LR23 & Aim to collect real time and non-real time data \\
\hline \multicolumn{2}{|c|}{$*=$ LECIM Requirements } \\
\hline
\end{tabular}

Table 7: LECIM MAC Requirements

\begin{tabular}{|c|c|}
\hline $\begin{array}{c}\text { Serial } \\
\text { Number }\end{array}$ & Description \\
\hline LMR1* & $\begin{array}{c}\text { Guaranteed link access on low duty cycle with } \\
\text { low energy (management frame from } \\
\text { coordinator for optimized configuration and } \\
\text { ease maintenance, link power management) }\end{array}$ \\
\hline LMR2 & $\begin{array}{c}\text { Support to fair access between near and far } \\
\text { nodes }\end{array}$ \\
\hline LMR3 & $\begin{array}{c}\text { Minimize contention on a link (distribute } \\
\text { access loads on slotted link, three grades of } \\
\text { link access) }\end{array}$ \\
\hline LMR4 & $\begin{array}{c}\text { Time-stamping (global time synchronization, } \\
\text { adjust clock drift with light overhead) }\end{array}$ \\
\hline LMR5 & Support to ease installation \\
\hline LMR6 & Support to ease maintenance \\
\hline LMR7 & Support to make network structure simple \\
\hline LMR8 & Optimized to network configuration \\
\hline$*$ LECIM MAC Requirements
\end{tabular}

\section{LECIM NETWORK MODEL AND TOPOLOGY}

The purpose of TG4k group is to facilitate single point to multi-thousands of point's communication for critical infrastructure monitoring. The main components of LECIM network are coordinator or collector, devices or end points, and repeater. Coordinator is generally mains powered, and endpoints are battery powered. Endpoints require mobility and supports portability for coordinator. They can communicate between each other [11]. Topology used in LECIM is star topology that supports one to multipoint communication as shown in the Figure 3. LECIM network consists of only one coordinator that supports many devices. Topology of LECIM network may vary and it could be as near node, far node, linear, group, distributed, and range [10].

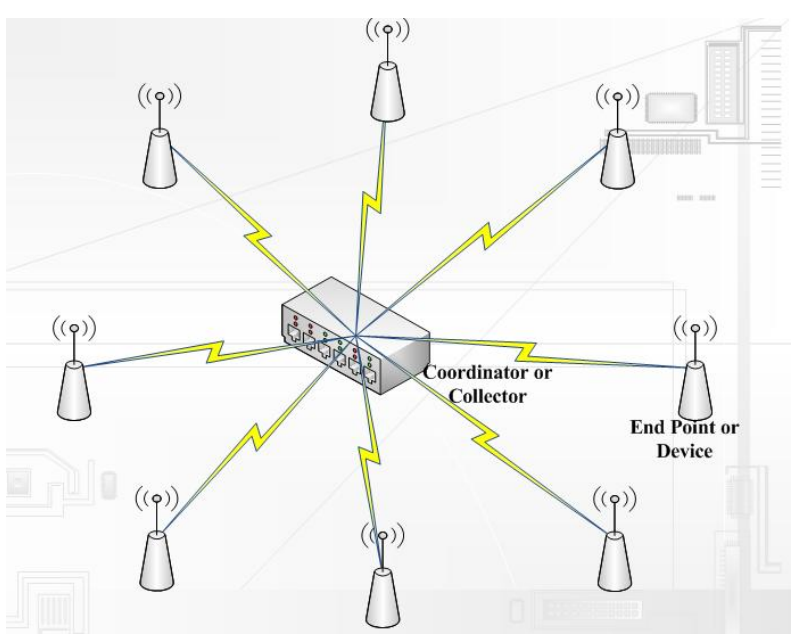

Figure 3: LECIM Topology 


\section{OPERATING FREQUENCY BANDS FOR LECIM}

Like IEEE 802.15.4, we propose three applicable frequency bands, and 27 channels with different bandwidth for LECIM networks. 16 channels are in $2.4 \mathrm{GHz}$ band, 10 channels are in $915 \mathrm{MHz}$ band and 1 channel is in the $868 \mathrm{MHz}$ frequency band for certain applications.

\section{EXISTING MAC PROTOCOLS FOR LECIM NETWORK}

The existing wireless technology can't gratify all the requirements of low energy based critical infrastructure monitoring applications. Towards developing a standard communication standard for LECIM applications IEEE task group $4 \mathrm{~K}$ has been formed under full supervision of IEEE 802.15 working group. Some important issues related to developing efficient LECIM applications can be summarized like, protection of the sensed data, accessing the shared medium in LECIM network; endpoints sleep time; proper coordination between coordinator and endpoints basically the way of knowing how the endpoints will know that the coordinator wants to send them the data is a challenging job where battery power must work for several years; lack of energy conservation mechanism, where most of the existing MAC protocols that support wireless sensor networks can't support this important issue; determining the status of the channel, in LECIM this is very important because most of the nodes in LECIM system are situated in long distance and the distance among the nodes are also long, the large number of endpoints are also a crucial factor. In order to solve this problem the existing contention-based and scheduled-based MAC protocols are not the appropriate solution, it needs to give more attention to solve the above mentioned problems. After forming the IEEE TG4k for LECIM applications solutions many researchers have denoted, designed, and proposed some MAC protocol for IEEE 802.15.4k standard. In this research paper the authors studied and analyzed the major criteria, advantages, and disadvantages of existing wireless sensor network (WSN) based MAC protocols along with new MAC proposals for LECIM network infrastructures and applications those are represented in Table 8.

Table 8: Study and analysis of new and existing MAC protocols for LECIM solutions

\begin{tabular}{|l|l|}
\hline \multicolumn{1}{|c|}{$\begin{array}{c}\text { Protocols towards } \\
\text { LECIM Solutions }\end{array}$} & \multicolumn{1}{|c|}{$\begin{array}{c}\text { Criteria, Advantages, and } \\
\text { Disadvantages }\end{array}$} \\
\hline WSNIRI [8] & $\begin{array}{l}\text { Proposed a low energy MAC. } \\
\text { Helps to Improve wakeup } \\
\text { mechanism because it maintains } \\
\text { and keeps the lowest end point } \\
\text { active duration supply for unicast } \\
\text { data model. }\end{array}$ \\
\hline Flexible MAC [12] & $\begin{array}{l}\text { Minimized network maintenance } \\
\text { message. Increasing the response } \\
\text { speed for alarming requirement of } \\
\text { 4K network because it support } \\
\text { shorter super-frame. Dynamic } \\
\text { time slot allocation scheme is used } \\
\text { 4k MAC flexible and efficient to } \\
\text { packet fragmentation and burst } \\
\text { packets. }\end{array}$ \\
\hline $\begin{array}{l}\text { Energy Efficient } \\
\text { MAC [13] }\end{array}$ & $\begin{array}{l}\text { Channel access description, and } \\
\text { packet structure definition } \\
\text { techniques are proposed. }\end{array}$ \\
\hline $\begin{array}{l}\text { Security based on } \\
\text { sensor networks [14] }\end{array}$ & $\begin{array}{l}\text { Ideas that ensure the protection of } \\
\text { critical infrastructure in WSN. }\end{array}$ \\
\hline
\end{tabular}

\begin{tabular}{|c|c|}
\hline $\begin{array}{l}\text { Roles for LECIM } \\
\text { protection [15] }\end{array}$ & $\begin{array}{l}\text { The authors provide an overview } \\
\text { of the main challenges and open } \\
\text { research issues on critical } \\
\text { information infrastructure security }\end{array}$ \\
\hline $\begin{array}{l}\text { Data survivability } \\
\text { model [16] }\end{array}$ & $\begin{array}{l}\text { Recognized and identified the } \\
\text { precise security requirements. The } \\
\text { symmetric keys and lightweight } \\
\text { key distribution techniques are } \\
\text { used for monitoring and could be } \\
\text { benefited for applications like } \\
\text { perimeter surveillance and } \\
\text { pipeline monitoring. }\end{array}$ \\
\hline $\begin{array}{l}\text { Ultra-lightweight key } \\
\text { [17] }\end{array}$ & $\begin{array}{l}\text { Proposed model helps to } \\
\text { maximize the amount of } \\
\text { monitoring-related data from } \\
\text { disaster after surviving. Set up } \\
\text { techniques for proper distribution } \\
\text { of sensors in LECIM applications. } \\
\text { Suitable for oil monitoring. }\end{array}$ \\
\hline $\begin{array}{l}\text { Improving medium } \\
\text { reliability [3] }\end{array}$ & $\begin{array}{l}\text { Proposed a model to improve } \\
\text { apparent reliability of the medium. } \\
\text { Shown a technique to acclimatize } \\
\text { LECIM PHYs to operate with } \\
\text { existing MAC. }\end{array}$ \\
\hline 4e TSCH [18] & $\begin{array}{l}\text { IEEE 802.15.4e time slotted } \\
\text { channel hopping (TSCH) resource } \\
\text { management scheme is proposed } \\
\text { for LECIM MAC. Techniques to } \\
\text { minimizing the negative effects of } \\
\text { multipath fading and interference } \\
\text { are discussed }\end{array}$ \\
\hline $\begin{array}{l}\text { MAC for wide area } \\
\text { monitoring [19] }\end{array}$ & $\begin{array}{l}\text { Projected and proposed contention } \\
\text { free low-energy link access for } \\
\text { LECIM by distributing the access } \\
\text { load on a slotted link. }\end{array}$ \\
\hline Flexible MAC [20] & $\begin{array}{l}\text { A flexible MAC proposal for } \\
\text { TG4k networks is presented. A } \\
\text { super frame structure is discussed } \\
\text { and time slot allocation-based } \\
\text { MAC is presented. }\end{array}$ \\
\hline $\begin{array}{ll}\text { Energy } & \text { Efficient } \\
\text { MAC [21] } & \end{array}$ & $\begin{array}{l}\text { A batch transmission MAC which } \\
\text { is based on IEEE 802.15.4e target } \\
\text { group is proposed. A basic } \\
\text { coordinated sleeping (CSL) } \\
\text { operation system is also projected } \\
\text { and proposed. }\end{array}$ \\
\hline T-MAC [22] & $\begin{array}{l}\text { The proposed protocol is used to } \\
\text { abridge or shorten the active } \\
\text { period if the channel is idle for a } \\
\text { short time. In the case of data and } \\
\text { information, the node remains } \\
\text { active till data reception or until } \\
\text { the active period ends. }\end{array}$ \\
\hline B-MAC [23] & $\begin{array}{l}\text { The proposed protocol operated } \\
\text { and utilized low power listening } \\
\text { (LPL) and an comprehensive } \\
\text { preamble to achieve low power } \\
\text { communication. }\end{array}$ \\
\hline X-MAC [24] & $\begin{array}{l}\text { A diminutive or short preamble } \\
\text { MAC protocol for duty-cycled } \\
\text { wireless sensor networks is } \\
\text { proposed. }\end{array}$ \\
\hline WiseMAC [25] & $\begin{array}{l}\text { It's an ultralow power MAC } \\
\text { protocol for the downlink of } \\
\text { infrastructure Wireless Sensor } \\
\text { networks. It is based on preamble }\end{array}$ \\
\hline
\end{tabular}




\begin{tabular}{|c|c|}
\hline & $\begin{array}{l}\text { sampling technique in which } \\
\text { endpoints sample the medium with } \\
\text { a constant period at regular } \\
\text { intervals. }\end{array}$ \\
\hline Zigbee [26] & $\begin{array}{l}\text { MAC and PHY for Low Rate } \\
\text { Wireless Personal Area Networks } \\
\text { (LR WPANs) are proposed. }\end{array}$ \\
\hline VLPM [27] & $\begin{array}{l}\text { Towards developing the MAC } \\
\text { protocol for wireless body area } \\
\text { networks a wakeup radio approach } \\
\text { is utilized that supports very low } \\
\text { power MAC features. }\end{array}$ \\
\hline $\begin{array}{l}\text { Radio-triggered } \\
\text { wakeups [28] }\end{array}$ & $\begin{array}{l}\text { Used for enormously or extremely } \\
\text { low power sensor network } \\
\text { applications. A wakeup signal } \\
\text { transmission and wakeup receiver } \\
\text { techniques are utilized containing } \\
\text { voltage multiplier and a digital } \\
\text { comparator. }\end{array}$ \\
\hline Wake-up radio [29] & $\begin{array}{l}\text { Low-power wake-up radio for } \\
\text { wireless sensor networks is } \\
\text { proposed. }\end{array}$ \\
\hline $\begin{array}{ll}\text { Durante } & \text { and } \\
\text { Mahlknecht [30] } & \end{array}$ & $\begin{array}{l}\text { An ultralow power wakeup } \\
\text { receiver for wireless sensor nodes } \\
\text { is presented. } \\
\text { The data rate and sensitivity are } \\
\text { high because of the amplification } \\
\text { stage, at the expense of power } \\
\text { consumption. }\end{array}$ \\
\hline $\begin{array}{l}\text { Micro-power sensor } \\
\text { node [31] }\end{array}$ & $\begin{array}{l}\text { Technique for ultra-low power } \\
\text { wake-up receivers for wireless } \\
\text { sensor networks is presented. For } \\
\text { developing the protocol the radio } \\
\text { frequency 'quasi-passive' wakeup } \\
\text { system along with adjustable } \\
\text { 'thresholds' technique are } \\
\text { proposed and used. It consists of } \\
\text { an envelope detector and an } \\
\text { amplifier. }\end{array}$ \\
\hline $\begin{array}{lr}\begin{array}{l}\text { Ultra-low } \\
\text { wake-up }\end{array} & \text { power } \\
\text { [32] } & \end{array}$ & $\begin{array}{l}\text { ULPWR-ultra-low power wake-up } \\
\text { receivers is proposed and } \\
\text { presented for wireless sensor } \\
\text { networks. The protocol design } \\
\text { based on high sensitivity } \\
\text { amplifiers, at the rate of power } \\
\text { consumption. }\end{array}$ \\
\hline 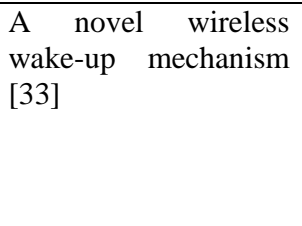 & $\begin{array}{l}\text { Authors projected and proposed a } \\
\text { novel wireless wake-up } \\
\text { mechanism for energy-efficient } \\
\text { ubiquitous networks which } \\
\text { replicated a solution with a bloom } \\
\text { filter. }\end{array}$ \\
\hline $\begin{array}{lll}\text { Low-cost } & \text { wake } & \text { up } \\
\text { radio [34] } & & \\
\end{array}$ & $\begin{array}{l}\text { Low-Cost wakeup radio for the } \\
868 \mathrm{MHz} \text { band sensor networks is } \\
\text { proposed. }\end{array}$ \\
\hline $\begin{array}{l}\text { Nanopower } \quad \text { wakeup } \\
\text { radio [35] }\end{array}$ & $\begin{array}{l}\text { A nanopower (nP) wakeup radio } \\
\text { circuit for wireless body area } \\
\text { networks is presented. It supports } \\
470 \mathrm{nW} \text { (nanowatt) idle listening } \\
\text { power. }\end{array}$ \\
\hline
\end{tabular}

\begin{tabular}{|l|l|}
\hline ALOHA MAC [36] & $\begin{array}{l}\text { A dynamic framed ALOHA MAC } \\
\text { for LECIM was proposed. The } \\
\text { main features are: a beacon } \\
\text { enabled super frame is used with } \\
\text { EAP and NAP periods (with GTS } \\
\text { for regular traffic), researchers } \\
\text { analyzed throughput for different } \\
\text { frame sizes and found optimum } \\
\text { network size and utilization factor. } \\
\text { Proposed protocol is simple to } \\
\text { implement and flexible in terms of } \\
\text { network size. }\end{array}$ \\
\hline
\end{tabular}

\section{EXISTING LECIM APPLICATIONS}

LECIM is the gracious and modern thought in wireless networking technology. Although it is a recent realization in technology but many proposals on the way to its proper application have already been proposed by researchers and in some cases some of the proposals are being implemented. Most of the LECIM applications including wireless environment in agriculture, container tracking, remote monitoring, soil monitoring, water leakage monitoring, distribution Grid and substation monitoring power monitoring, car parking monitoring, location tracking applications and many more found in the literatures gave emphasized over real time information collection using sensors. The network that will be used for the remote monitor must have some common characteristics including real-time control and quick actions; security; cost reduction; improve customer services; and updating real time status. Upon studied the relevant documents presented to IEEE in support of the proposed standard, the researchers in this paper found an excellent number of proposals for LECIM applications. LECIM needs a standard solution, so after analyzing the relevant documents the authors of this research paper tried to find the major requirements, challenges and limitations that is key factors behind those LECIM applications as shown in Table 9. This analytical proof will help other researchers and academicians to further study and research on this field and find new applications to help the community. 
Table 9: Major LECIM Applications and Their Key Factors

\begin{tabular}{|c|c|}
\hline $\begin{array}{c}\text { LECIM } \\
\text { Applications }\end{array}$ & Key Factors \\
\hline $\begin{array}{l}\text { Water Leakage } \\
\text { Detection [37] }\end{array}$ & $\begin{array}{l}\text { Underground logging systems that are } \\
\text { large number of sensors those are } \\
\text { permanently installed. } \\
\text { Long Range. } \\
\text { Long lifetime battery. } \\
\text { Small data message and alarm event } \\
\text { for leak detection } \\
\text { Low installation and maintenance cost } \\
\text { Easy deployment }\end{array}$ \\
\hline $\begin{array}{l}\text { Oil and Gas } \\
\text { Pipeline } \\
\text { Monitoring [37] }\end{array}$ & $\begin{array}{l}\text { Major challenge: Pipeline sabotage, } \\
\text { vandalism and security related issues. } \\
\text { It ultimately increases operational } \\
\text { costs, lost revenue and damage to } \\
\text { corporate image. } \\
\text { It is very important to monitor and } \\
\text { protect pipelines for failures, damage } \\
\text { and theft. } \\
\text { Key factors: } \\
\text { Safety (human / environment) } \\
\text { Reliability (critical resources) } \\
\text { Cost savings (increasing cost) } \\
\text { Compliance (regulators) }\end{array}$ \\
\hline $\begin{array}{l}\text { Container } \\
\text { tracking [38] }\end{array}$ & 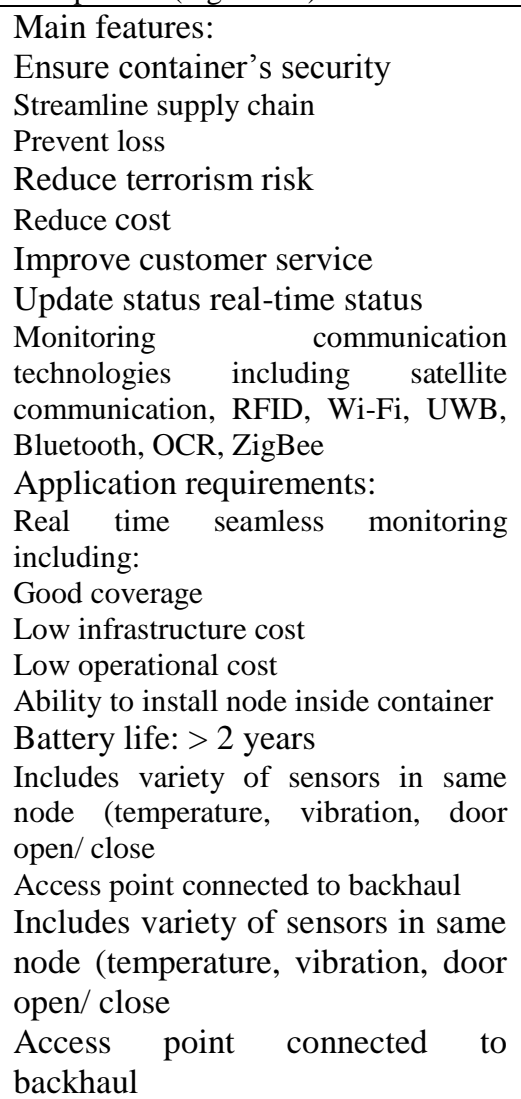 \\
\hline Agriculture [39] & $\begin{array}{l}\text { Green House: } \\
\text { Information in Green house collected } \\
\text { by sensors. Major information like: } \\
\text { Temperature } \\
\text { Humidity } \\
\mathrm{PH}, \mathrm{CO} 2 \text { and other soil factors. } \\
\text { Communication networks implement } \\
\text { the remote monitor, real-time control }\end{array}$ \\
\hline
\end{tabular}

\begin{tabular}{|c|c|}
\hline & $\begin{array}{l}\text { and quick actions. } \\
\text { Communication technology: } \\
\text { GPRS/GSM/3G, Internet, WPAN, but } \\
\text { WPAN and 3G is an excellent } \\
\text { application } \\
\text { Key factors related to smart } \\
\text { agriculture: } \\
\text { Super Power Consumption } \\
\text { Networking support: Large scale } \\
\text { network to cover wide fields, Mesh or } \\
\text { Super-Tree Networking for } \\
\text { complicated environment, Connecting } \\
\text { WPAN with Mobile Networks. } \\
\text { Reliability and Cost }\end{array}$ \\
\hline $\begin{array}{l}\text { Remote } \\
\text { monitoring: } \\
\text { Smart Buoys } \\
{[40]}\end{array}$ & $\begin{array}{l}\text { Application challenges: different user } \\
\text { vessels, minimum maintenance cost } \\
\text { Main features: Guarantee protected } \\
\text { and secure mooring, confirm real time } \\
\text { monitoring, prevent loss of buoys, } \\
\text { ensure payment of service, reduce cost, } \\
\text { and improve customer service. } \\
\text { Monitoring communication } \\
\text { technologies including satellite } \\
\text { communication and GSM. } \\
\text { Application requirements for real time } \\
\text { monitoring that supports: } \\
\text { Good coverage } \\
\text { Low infrastructure cost } \\
\text { Low operational cost } \\
\text { Ability to install node inside buoys } \\
\text { Battery life: }>1 \text { year } \\
\text { Includes variety of sensors in same } \\
\text { node } \\
\text { Several square miles coverage with } \\
\text { hundreds of buoys }\end{array}$ \\
\hline $\begin{array}{l}\text { Remote } \\
\text { monitoring: } \\
\text { Smart water } \\
\text { meters, Smart } \\
\text { gas meters [40] }\end{array}$ & $\begin{array}{l}\text { Application challenges: } \\
\text { Bidirectional communication between } \\
\text { system and meter } \\
\text { Large number of meters within urban } \\
\text { areas } \\
\text { Large area of coverage for rural } \\
\text { areas } \\
\text { Main features: } \\
\text { Monthly, daily, 15-min measuring } \\
\text { Measuring on demand } \\
\text { Dynamic pricing } \\
\text { Reduce cost } \\
\text { Improve customer service } \\
\text { Metering communication technologies } \\
\text { including PLC (Power Line } \\
\text { Communication), GSM, Euridis and } \\
\text { ZigBee }\end{array}$ \\
\hline $\begin{array}{l}\text { Soil Monitoring } \\
\text { [41] }\end{array}$ & $\begin{array}{l}\text { Application challenges: } \\
\text { Sensors need to be installed in the soil } \\
\text { once the crop is planted and removed } \\
\text { at the end of the season. } \\
\text { The solar power and antenna need to } \\
\text { extend above the bio mass. } \\
\text { Farmland may or may not have cellular } \\
\text { connectivity. } \\
\text { Requirements: } \\
\text { Ability to install node inside } \\
\text { measurement probe. Same node used } \\
\text { worldwide to ensure single product } \\
\text { design. }\end{array}$ \\
\hline
\end{tabular}




\begin{tabular}{|c|c|}
\hline & $\begin{array}{l}\text { Low power consumption. } \\
\text { Access point connected to wired or } \\
\text { wireless internet connection. } \\
\text { Very high up-times with self recovery } \\
\text { in case of break downs. No technical } \\
\text { staff nearby. } \\
\text { Real time seamless monitoring } \\
\text { including: } \\
\text { Good coverage }-10 \text { miles or better } \\
\text { Low infrastructure cost } \\
\text { Low operational cost }\end{array}$ \\
\hline $\begin{array}{l}\text { Electronic } \\
\text { Equipment } \\
\text { Monitoring } \\
{[42]}\end{array}$ & $\begin{array}{l}\text { Major challenges: } \\
\text { Find fault circuit quickly, } \\
\text { Prevent from stolen or damage. } \\
\text { Major requirements: } \\
\text { Small data packet } \\
\text { Long distance transmission } \\
\text { Anti-Interference }\end{array}$ \\
\hline $\begin{array}{l}\text { Location } \\
\text { Tracking } \\
\text { Application } \\
\text { [43] }\end{array}$ & 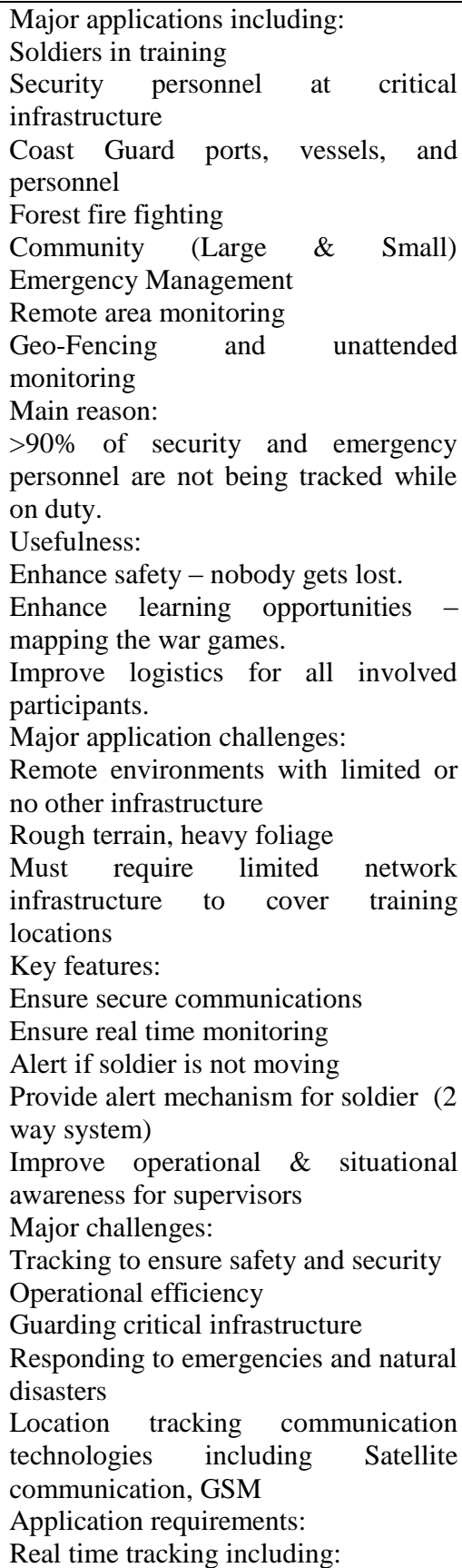 \\
\hline
\end{tabular}

\begin{tabular}{|c|c|}
\hline & $\begin{array}{l}\text { Long range coverage } \\
\text { Low infrastructure cost } \\
\text { Low operational cost } \\
\text { Battery life: Several days } \\
\text { Two way communication for alerting } \\
\text { and acknowledgements } \\
\text { High level of security and reliability } \\
\text { Option to integrate location data with a } \\
\text { host of legacy location awareness } \\
\text { applications } \\
\text { Option to operate entire system as a } \\
\text { mobile entity }\end{array}$ \\
\hline $\begin{array}{l}\text { Distribution } \\
\text { Grid and } \\
\text { Substation } \\
\text { Monitoring [44] }\end{array}$ & $\begin{array}{l}\text { Areas of applications: } \\
\text { Distribution Grid Sensor or Fault } \\
\text { Current Indicators. } \\
\text { Key features: } \\
\text { In the tens of thousands } \\
\text { Overhead and underground } \\
\text { Monitor state, possibly number of } \\
\text { events } \\
\text { Distribution Transformers. } \\
\text { Key features: } \\
\text { In the hundreds of thousands } \\
\text { Voltage and current, power out } \\
\text { Monitoring Remote Terminal Units. } \\
\text { Key features: } \\
\text { Condition based monitoring } \\
\text { Improve outage resolution }\end{array}$ \\
\hline
\end{tabular}

\section{CONCLUSION}

The IEEE 802.15.4k task group is intended as an improvement to IEEE 802.15.4 to support and facilitate point to multipoint communication for LECIM devices. TG4k is formed to address the LECIM. LECIM networks are anticipated to perform significant roles in supporting the monitoring and management needs of critical infrastructure applications and networks management. It's a very recent and modern research arena and there are a huge scopes for the researchers to contribute their skills, knowledge and interests in this field. The main issues related to this research ground are low energy consumption, low data rate, long battery life, low cost and scalability. Still there is no protocol standard for LECIM that supports all these criteria mentioned previously, so there is an enormous scope to work on it. In this paper towards designing and developing an efficient LECIM network all the major characteristics, requirements, existing LECIN networks model, topology and frequency bands; existing MAC protocol for LECIM networks, and existing LECIM applications with their potentiality, merit and demerit are studied, analyzed, and exploited. This will help the researchers for further study, and exploration towards improving LECIM as a whole. 


\section{REFERENCES}

[1] Critical Infrastructure_ basic information http://en.wikipedia.org/wiki/Critical_infrastructure

[2] Joaquin Silva, 'Low Energy Critical Infrastructure Monitoring', 15-10-0528-00-leci-low-energy-criticalinfrastructure-monitoring.pptx

[3] Benjamin Rolfe, Preliminary Fragmentation Proposal for TG4k, 15-11-0478-00-004k-fragmentation-proposal-fortg4k.pptx

[4] David A. Howard, IEEE 802.15.LECIM Interest Group Call For Applications, doc: IEEE P802.15-15-10-012800-leci

[5] https://mentor.iee.org/802.15/dcn/10/15-10-0053-00wng0-low-energy-critical-iinfrastructure monitoring.pptx

[6] https://mentor.ieee.org/802.15/dcn/10/15-10-0053-00wng0-low-energy-critical-iinfrastructure-monitoring.pptx

[7] David Howard, SG Low Energy, Critical Infrastructure Monitoring (LECIM) Project Draft PAR, 15-10-0756-09leci-sglecim-par-draft.docx

[8] Yang Yang, Xiang Wang, Heqing Huang, Jie Shen, Tao Xing, Haitao Liu, Betty Zhao' 'Low Energy MAC Proposal for TG4k WSNIRI', 15-11-0596-00-004kwsniri-low-energy-mac-proposal-for-tg4k.ppt

[9] Kyungsup Kwak, Jaedoo Huh, Hyung Soo Lee, M. Al Ameen, Niamat Ullah, M.S. Chowdhury, 'A Dynamic Framed Slotted ALOHA protocol for LECIM Networks', 15-11-0486-03-004k-inha-etri-tg4kproposal.pptx

[10] Seong-Soon Joo, Jong-Arm Jun, Cheol-Sig Pyo, MAC Proposal for Low-Energy Wide Area Monitoring, 15-110597-00-004k-lecim-mac-proposal-for-tg4k.ppt

[11] P. Kinney, "LECIM Call for Proposals, IEEE P802.1511-0147-02-004k, https://mentor.ieee.org/802.15/documents

2011 ,

12] Yong Li, Ping Wang, Heng Wang, 'A Flexible MAC Proposal for TG4k Networks', 15-11-0606-01-004k-aflexible-mac-proposals-for-tg4k-networks.ppt

[13] Hao Liu, Guolian Yao, Pingping Xu, 'Energy Efficient MAC protocol for Low Energy Critical Infrastructure Networks', 15-11-0619-00-004k-energy-effi-mac-forlecim.ppt

[14] J. Lopez, J. A. Montenegro, and R. Roman, "Serviceoriented security architecture for CII based on sensor networks," in 2nd International Workshop on Security, Privacy and Trust in Pervasive and Ubiquitous Computing (SecPerU '06), pp. 1-6, June 2006.

[15]R. Roman, C. Alcaraz, and J. Lopez, "The role ofWireless Sensor Networks in the area of Critical Information Infrastructure Protection," Information Security Technical Report, vol. 12, no.1, pp. 24-31, 2007.

[16] M. Albano, S. Chessa, and R. Di Pietro, "A model with applications for data survivability in Critical Infrastructures," International Journal of Information Assurance and Security, vol. 4, pp. 629-639, 2009

[17] K. M. Martin and M. B. Paterson, "Ultra-lightweight key pre distribution in wireless sensor networks for monitoring linear infrastructure," in 3rd IFIP WG 11.2 International Workshop on Information Security Theory and Practice (WISTP '09), vol. 5746 of Lecture Notes in Computer Science, pp. 143-152, 2009.

[18] J. Schwoerer and N. Dejean, "Elster \& France Telecom proposal, doc.: IEEE 802. 15-11-0479-01-004k," 2011, https://mentor.ieee.org/802.15/documents
[19] S. S. Joo, J. A. Jun, and C. S. Pyo, "MAC Proposal for Low-Energy Wide Area Monitoring, doc.: IEEE 802. 1511-0597-01-004k,"2011, https://mentor.ieee.org/802.15/documents.

[20] Y. Li, P. Wang, and H. Wang, "A Flexible MAC Proposal for TG4k Networks, doc.: IEEE 802. 15-110606-01-004k,"2011, https://mentor.ieee.org/802.15/documents

[21] H. Liu, G. Yao, and P. Xu, "Energy Efficient MAC protocol for Low Energy Critical Infrastructure Networks, doc.: IEEE 802.15-11-0619-01-004k," 2011, https://mentor.ieee.org/802.15/documents

[22] T. Van Dam and K. Langendoen, "An adaptive energy efficient MAC protocol for wireless sensor networks," in 1st International Conference on Embedded Networked Sensor Systems (SenSys '03), pp. 171-180, Los Angeles, Calif, USA, November 2003.

[23] J. Polastre, J. Hill, and D. Culler, "Versatile low power media access for wireless sensor networks," in 2nd International Conference on Embedded Networked Sensor Systems (SenSys '04), pp. 95-107, NewYork, NY, USA, November 2004.

[24] M. Buettner, G. V. Yee, E. Anderson, and R. Han, "XMAC: a short preamble MAC protocol for duty-cycled wireless sensor networks," in 4th International Conference on Embedded Networked Sensor Systems (SenSys '06), pp. 307-320, New York, NY, USA, November 2006.

[25] A. El-Hoiydi and J. D. Decotignie, "WiseMAC: an ultra low power MAC protocol for the downlink of infrastructure Wireless Sensor networks," in 9th International Symposium on Computers and Communications (ISCC '04), pp. 244-251, July 2004.

[26] IEEE, "Wireless Medium Access Control (MAC) and Physical Layer (PHY) specifications for Low Rate Wireless Personal Area Networks (LR-WPANS)," IEEE 802.15.4-2003, 2003

[27] N. Ullah, P. Khan, and K. S. Kwak, "A very low power MAC (VLPM) protocol for wireless body area networks," Sensors, vol. 11, no. 4, pp. 3717-3737, 2011

[28] J. Ansari, D. Pankin, and P. M"ah"onen, "Radio-triggered wakeups with addressing capabilities for extremely low power sensor network applications," International Journal of Wireless Information Networks, vol. 16, no. 3, pp. 118-130, 2009.

[29] P. Le-Huy and S. Roy, "Low-power wake-up radio for wireless sensor networks," Mobile Networks and Applications, vol. 15, no. 2, pp. 226-236, 2010

[30] M. S. Durante and S.Mahlknecht, "An ultra low power wakeup receiver for wireless sensor nodes," in 3rd International Conference on Sensor Technologies and Applications (SENSORCOMM '09), pp. 167-170, June 2009.

[31] M.Malinowski,M.Moskwa, M. Feldmeier, M. Laibowitz, and J. A. Paradiso, "CargoNet: a low-cost micro-power sensor node exploiting quasi-passive wakeup for adaptive asynchronous monitoring of exceptional events," in 5th ACM Conference on Embedded Networked Sensor Systems (SenSys '07), pp. 145-159, November 2007.

[32] N. Pletcher and J. M. Rabaey, "Ultra-low power wake-up receivers for wireless sensor networks," Tech. Rep. UCB/EECS-2008-59, EECS Dept, Univ. of California, Berkeley, Calif, USA, May 2008.

[33] T. Takiguchi, S. Saruwatari, T. Morito, S. Ishida, M. Minami, and H. Morikawa, "A novel wireless wake-up 
mechanism for energy-efficient ubiquitous networks," in IEEE International Conference on Communications Workshops (ICC '09), June 2009.

[34] B. V. der Doorn, W. Kavelaars, and K. Langendoen, "A prototype Low-Cost wake up radio for the $868 \mathrm{MHz}$ band," International Journal of Sensor Networks, vol. 5, no. 1, pp. 22-32, 2009

[35] S. Marinkovic and E. Popovici, "Nano-power Wake-Up Radio circuit for wireless body area networks," in IEEE Radio and Wireless Symposium (RWS '11), pp. 398401, January 2011

[36] Kyungsup Kwak, Jaedoo Huh, Hyung Soo Lee, M. Al Ameen, Niamat Ullah, M.S. Chowdhury, 'A Dynamic Framed Slotted ALOHA protocol for LECIM Networks', 15-11-0486-03-004k-inha-etri-tg4k-proposal.pptx

[37] Johan Becker, Mike Calcagno, David Howard, 'Low Energy Critical Infrastructure Monitoring', 15-10-005300-wng0-low-energy-critical-iinfrastructuremonitoring.pptx

[38] Roberto Aiello, 'Container Monitoring Application', 1510-0186-00-leci-container-tracking-application.pptx
[39] Liang Zhang, Bo Hu, Z.F. Zhao, Tao Xing, Haitao Liu, Betty Zhao, 'Super-low Energy Consumption WPAN Application Case: Wireless Environment Monitor in Smart Agriculture', 15-10-0291-00-leci-super-lowenergy-consumption-wpan-application-case-wirelessenvironment-monitor-in-smart-agricultur.ppt

[40] Nikica Mikulandra, 'Remote Monitoring Applications', 15-10-0297-01-leci-remote-monitoring-applications.pptx

[41] Peter Ellegaard, 'Soil Monitoring Application', 15-100299-00-leci-soil-monitoring-application.ppt

[42] JF Luo, Y Yang, Y X Fu, J Shen, X Wang, X Tao, Haituo Liu, L Li, 'Low Energy Critical Infrastructure Monitoring Application in China', 15-10-0307-00-lecilow-energy-critical-infrastructure-monitoringapplication-in-china.pptx

[43] Stephen Gamache, 'Location Tracking Applications', 1510-0519-00-leci-location-tracking-application.pptx

[44]Mike Calcagno, 'Use Case: Distribution Grid and Substation Monitoring', 15-10-0529-00-leci-use-casedistribution-grid-and-substation-monitoring.pptx 